\title{
A Case Study on Medovriddhi WSR to Obesity
}

\section{Verma $R^{*}$}

Government Ayurveda College, India

*Corresponding author: Roshani Verma MD, Swasthavritta AMO, Government Ayurveda College, Burhanpur, MP, India, Tel: 8878032205, 7987238248; Email: dr.roshaniverma@gmail.com

\section{Case Report}

Volume 2 Issue 8

Received Date: November 29, 2018

Published Date: December 17, 2018

DOI: $10.23880 /$ jonam- 16000160

\section{Abstract}

Medovriddhi or Obesity is one of the commonest lifestyle disorders. This case study represents holistic approach of Ayurveda is effective in its treatment. Relief in various symptoms and change in parameters proved that the holistic approach is very effective in this disorder.

Keywords: Medovriddhi; Ayurveda; Global Food Markets; Cardiovascular Disease

\section{Introduction}

The world is facing with many lifestyle disorders. Lifestyle disorders are being raised because of unbalanced food, sedentary lifestyle and stressful mental conditions. Obesity is one of the commonest disorders. In India, obesity has reached epidemic proportions in the $21^{\text {st }}$ century with morbid obesity affecting $5 \%$ of the total population [1]. Unhealthy, processed food has become much more accessible following country's continued integration in global food markets [2]. Obesity is a major risk factor for cardiovascular disease. Indian Heart Association has been raising awareness about it [3]. India has second highest obese children in the world, which is 14.4 million [4]. Normal BMI 18.0-22.9 kg/m², Overweight $23.0-24.9 \mathrm{~kg} / \mathrm{m}^{2}$ and Obesity $>25 \mathrm{~kg} / \mathrm{m}^{2}$. According to guidelines for diagnosis of obesity and abdominal obesity for India have been published in JAPI (2009) that a BMI over $23 \mathrm{~kg} / \mathrm{m}^{2}$ is considered overweight [5]. In Ayurveda, this condition can be called as Medovriddhi, which is due to excess formation of Meda, which accumulates in the body tissue. Obesity can be cured and prevented as well with holistic approach of Ayurveda. So, we are discussing a case study of a patient of obesity, who had tired of many medicines and therapies; we dealt that patient with combination of Aushadha, Ahara, Vihara which is the basic treatment pattern of Ayurveda to treat Medovriddhi or obesity and the result was appreciating.

\section{Material and Methods}

In this case study a female patient whose age was 39 years, weight was $93 \mathrm{~kg}$, height was $163 \mathrm{~cm}$ and BMI was 35 had taken.

\section{History \& Lifestyle}

Religion: Hindu

Education: Higher secondary

Occupation: Boutique

Marital status: Married

Socioeconomic status: Middle class associated disease; Hypothyroidism since 4 years, Hyperlipidemia since 1 year.

Family history: Hyperlipidemia, Diabetes mellitus, IHD

Emotional make-up: Normal

Veg/Non veg: Non veg, freq. 1-2/week

Type of Ahara: Adhyashana mostly

Dominant Guna in diet: Guru, Snigdha

Dominant Rasa in diet: Lavana

Freq. of fast-food intake: 4 days/week

Sleeping hours; in a day: 1 hour, in a night: 9 hours

Exercise: walking $30 \mathrm{~min}$ day 


\section{Journal of Natural \& Ayurvedic Medicine}

\section{Addiction: Tea}

\section{Dashavidha Pareeksha}

Prakriti: Vata-Kaphaja Vikriti: Kapha Pradhana

Sara: Madhyama Samhanana: Madhyama

Pramana: Madhyama Satmya: Madhyama

Satva: Madhyama Aharashakti: Pravara

Vyayamshakti: Madhyama Vaya: Yuva

\section{Method}

This patient had advised to take Haritakishunthi churna, Surya Namasar and specific Ahara explained in diet chart. The diet chart included Apatarpaka, Ruksha Guna Pradhana Ahara. Duration of treatment was two months.

\section{Result}

Result was quite interesting and more than expectations (Table 1).

\begin{tabular}{|c|c|c|}
\hline Parameters & Before T/t & After T/t \\
\hline Weight & 93 & 82 \\
\hline BMI & 35 & 30.86 \\
\hline Body fat\% & 45.57 & 40.67 \\
\hline \multicolumn{2}{|c|}{ Measurements } \\
\hline Rt. Mid Arm & 37 & 34 \\
\hline Chest & 100.5 & 96.5 \\
\hline Abdomen & 90.5 & 86 \\
\hline Mid-thigh & 61 & 57 \\
\hline Leg & 45.8 & 42 \\
\hline Hip & 110 & 107 \\
\hline Waist & 85 & 79.5 \\
\hline HDL & 48 & 49 \\
\hline LDL & 159.27 & 139.35 \\
\hline VLDL & 20 & 19.8 \\
\hline S. Cholesterol & 227.27 & 208.15 \\
\hline S. Triglyceride & 100.2 & 99.1 \\
\hline Risk factor & 4.7 & 4.2 \\
\hline Blood sugar (fasting) & 99.1 & 78.26 \\
\hline
\end{tabular}

Table 1: Evaluation of Parameters.

There is a relief in symptoms of Medovriddhi (obesity) like Anga Gaurav, Kshudha Adhikya, Nisha Mutrata, Chal
Sphika, Chal Udara, Chal Stana, Anga Shaithilya, Gatra Sadan, Utsaha Hani, Nidra Adhikya, Tandra, Klama and Snigdha Gatrata.

\section{Discussion}

Medovriddhi (obesity) is a Santarpanajanya Vyadhi and its treatment is indicated as Apatarpana, Laghu, Ruksha Chikitsa in various Ayurvedic Samhita. The treatment which was used in this case was Haritakishunthi Churna, which has characteristic of Laghu, Ushna, Ruksha, Medohara, Vataghna etc. properties. Diet chart included Barley, walnut, milk, turmeric, amla, daliya, fruits etc. Which are Laghu, Apatarpaka and nutritious in nature. Surya Namaskar is a whole body exercise, which is helpful in losing weight and has many physical, mental and emotional benefits. Weight reduction and relief in various symptoms indicates that the given treatment was so effective.

\section{Conclusion}

There are a lot of choices for the treatment of Medovriddhi (obesity). In Ayurveda, here is a concept of Aushadha, Ahara and Vihara for any particular disease. Obesity can't be controlled only through medicines only. Proper diet and exercise have their importance in it. And in this case study it has proved that holistic approach is necessary for complete cure of a disease.

\section{References}

1. (2000) India facing obesity epidemic: experts. The Hindu.

2. Gulati S, Misra A (2017) Abdominal obesity and type 2 diabetes in Asian Indians: Dietary strategies including edible oils, cooking practices and sugar intake. Eur J Clin Nutr 71(7): 850-857.

3. (2015) Indian Heart Association.

4. (2015) A study published in the New England Journal of Medicine.

5. Misra A, Chowbey P, Makkar BM, Vikram NK, Wasir, JS, et al. (2009) Consensus statement for diagnosis of obesity, abdominal obesity and the metabolic syndrome for Asian Indians and recommendations for physical activity, medical and surgical management. J Assoc Physicians India 57: 163-170. 